\title{
EFFECT OF VARIOUS KINDS OF PHOSPHORUS FERTILIZERS ON A PEAT SOIL
}

\author{
Armi KaIla \\ University of Helsinki, Department of Agricultural Chemistry
}

Received May 25, 1958

In 1930 a field trial was started in Leteensuo Experiment Station of Suomen Suoviljelysyhdistys (Peat Cultivation Society of Finland) in order to compare the effect of superphosphate with that of basic slag in a fen soil. This experiment was run according to the original plan for 18 years or until 1947. In the following year, instead of basic slag, finely ground rock phosphate was applied, and since that spring the trial has for ten years been treated according to this new plan.

The prehistory of this trial decreases, of course, its value as a comparison of superphosphate and rock phosphate. In 1948, when rock phosphate was used for the first time the crop was timothy ley of the third year. In 1957 or in the year of the tenth treatment the crop was the same ley which then was 12 years old. Thus rock phosphate as well as superphosphate had to be applied as surface dressing for all these 10 years. The use of rock phosphate in this way is not recommendable and it seldom occurs in practical farming.

At present, the trial may be considered to compare the effect of superphosphate with that of rock phosphate as surface dressing after pretreatments with superphosphate and basic slag, respectively. Even as such the trial is not without interesting points. Since the Board of Suoviljelysyhdistys in 1956 kindly allowed the author to collect soil samples from this trial, an attempt was made to study the possible differences in the nutrient conditions of the variously treated plots. In addition to this, hay samples of the yield in 1957 were put at the author's disposal, and so were also series of samples from the various layers of the plots.

\section{Material}

The field trial lies on a soil of fairly well humified wood-Carex peat. The land was reclaimed in 1928 from a spruce-broadleaved tree swamp. It was clayed in 1930 with $100 \mathrm{~m}^{3} / \mathrm{ha}$ and in 1941 with $200 \mathrm{~m}^{3} / \mathrm{ha}$. In 1930 a part of the area was treated with $2000 \mathrm{~kg} / \mathrm{ha}$ of slaked lime. 
The experiment includes eight treatments in four replications:

A. Unlimed: $1.0=$ no phosphate

2. $\mathrm{P}$ super $=100 \mathrm{~kg} / \mathrm{ha}$ of $20 \%$ superphosphate

3. $\mathrm{P}$ rock $=130 \mathrm{~kg} / \mathrm{ha}$ of ground rock phosphate

4. $2 \mathrm{P}$ super $=200 \mathrm{~kg} /$ ha of $20 \%$ superphosphate

5. $2 \mathrm{P}$ rock $=260 \mathrm{~kg} / \mathrm{ha}$ of ground rock phosphate

B. Limed:

6. $0=$ no phosphate

7. $2 \mathrm{P}$ super $=200 \mathrm{~kg} /$ ha of $20 \%$ superphosphate

8. $2 \mathrm{P}$ rock $=260 \mathrm{~kg} / \mathrm{ha}$ of ground rock phosphate

Basic slag which in 1948 was replaced by rock phosphate was applied in amounts containing citric acid soluble $\mathrm{P}_{2} \mathrm{O}_{5}$ as much as the corresponding amount of superphosphate contained ammonium citrate soluble $\mathrm{P}_{2} \mathrm{O}_{5}$, or 20 and $40 \mathrm{~kg} / \mathrm{ha}$, respectively.

All the plots were annually treated with equal amounts of $40 \%$ potash fertilizer. No other nutrients were applied.

Soil samples were collected in September 1956 from the ploughing layer of all the plots. Late in the autumn 1957 samples from the various layers down to the depth of $70 \mathrm{~cm}$ were taken with a special bore. The latter set of samples was available only from one plot of each treatment.

Hay samples from all the experimental plots were collected in the summer 1957 .

\section{Methods}

$\mathrm{pH}$ was directly measured from the fresh soil samples with a Beckman pH-meter using glass electrode.

All the other analyses were performed on air-dried and ground samples.

The potassium and calcium conditions of soil were characterized by the amounts of these cations extracted with $1 \mathrm{~N}$ ammonium chloride solution (3).

Total nitrogen in soil and hay samples was determined by a modified Kjeldahl procedure which also allowed the colorimetric determination of total phosphorus and the flamephotometric estimation of total potassium from the same digest.

Inorganic phosphorus in the soil samples was characterized in several ways. The total amount was determined by the acid-alkali extraction used for the determination of total organic phosphorus (4). Acid soluble phosphorus is represented by phosphorus extracted with $0.2 \mathrm{~N}$ sulphuric acid in the ratio of 1 to 100 , the time of extraction being one hour. The nexchangeable» phosphorus and the corresponding phosphorus concentration in soil solution were determined according to the method developed by TERÄSVUORI (6); only the ratio of soil to solution was lowered to half of that used by Teräsvuori for mineral soils, and heating of the mixtures of soil and phosphate solutions on open flame was substituted by heating on a boiling waterbath.

The hay samples were analyzed for organic and inorganic phosphorus by the shortened modification of the fractionation method developed by the author (2). Calcium and magnesium in hay were determined from ash solution by the versenate method. 


\section{Results}

Attention must be paid to the fact that the plots were clayed in 1941 and since that spring they have been ploughed and cultivated only a few times. Therefore, the clay is not yet uniformly distributed, and owing to this a marked variation in the analytical results may be expected.

Some of the general characteristics of the soil samples from the ploughing layer are reported in Table 1 . The seemingly quite marked differences between the

Table 1. $\mathrm{pH}$ and contents of ash, total nitrogen and extractable calcium and potassium in the soil samples

\begin{tabular}{|c|c|c|c|c|c|}
\hline \multirow{2}{*}{ Treatment } & \multirow{2}{*}{$\mathrm{pH}$} & \multirow{2}{*}{$\begin{array}{c}\text { Ash } \\
\%\end{array}$} & \multirow{2}{*}{$\begin{array}{c}\text { Tot. } \mathrm{N} \\
\% \text { of org. } \\
\text { dry matter }\end{array}$} & \multicolumn{2}{|c|}{ Extractable } \\
\hline & & & & $\begin{array}{c}\mathrm{Ca} \\
\text { ppm }\end{array}$ & $\begin{array}{c}\mathbf{K} \\
\text { ppm }\end{array}$ \\
\hline Unlimed $\quad 0$ & 4.2 & 36.2 & 3.55 & 5500 & 420 \\
\hline P super & 4.3 & 39.9 & 3.42 & 5800 & 200 \\
\hline $\mathrm{P}$ rock & 4.4 & 43.6 & 3.36 & 5200 & 160 \\
\hline $2 \mathrm{P}$ super & 4.3 & 43.8 & 3.56 & 5900 & 160 \\
\hline $2 \mathrm{P}$ rock & 4.4 & 42.7 & 3.57 & 5700 & 190 \\
\hline Limed $\quad 0$ & 4.5 & 44.9 & 3.46 & 6500 & 340 \\
\hline $2 \mathrm{P}$ super & 4.6 & 44.6 & 3.49 & 8600 & 170 \\
\hline $2 \mathrm{P}$ rock & 4.6 & 47.4 & 3.58 & 7800 & 180 \\
\hline L.S.D. $\quad 5 \%$ & 0.4 & 11.2 & 0.17 & 2300 & 70 \\
\hline
\end{tabular}

variously treated soils are mostly not statistically significant. This is particularly the case in regard to the ash content which, obviously, reflects the non-uniform distribution of clay in the soil. The samples from the plots limed in 1930 tend to be somewhat less acid than the samples from the unlimed plots. Also the content of extractable calcium seems to be higher in the former samples. The amounts of extractable potassium in the plots without any phosphate application are markedly higher than even those in the plots with the lower phosphate treatment. This, of course, may be attributed to the low need of potassium by the small yield produced in the former plots (cf. Table 4). No distinct effect of the various treatments on the total nitrogen content of the organic dry matter can be detected.

In Table 2 data are recorded which characterize the phosphorus conditions in the ploughing layer of the variously treated plots. The total amount of inorganic phosphorus is fairly low as it generally is in Finnish peat soils, even in the cultivated ones. The effect of phosphate applications is reflected in these values although the large variation in many cases hampers the occurence of statistically significant differences. This holds true also in regard to the acid soluble phosphorus. This fraction probably represents a mixture of both calcium and sesquioxide bound phosphorus. The mexchangeablen phosphorus was extracted by $0.1 \mathrm{~N} \mathrm{~K}_{2} \mathrm{CO}_{3}-\mathrm{KOH}$ solution and it gives a picture of the sesquioxide bound phosphorus. According to TERÄsvUORI (6), 
Table 2. Inorganic $P$ in the ploughing layer

\begin{tabular}{|c|c|c|c|c|}
\hline Treatment & $\begin{array}{c}\text { Total } \\
\mathrm{mg} / \mathrm{kg}\end{array}$ & $\begin{array}{l}\text { Soluble in } \\
0.2 \mathrm{~N} \mathrm{H}_{2} \mathrm{SO}_{4} \\
\mathrm{mg} / \mathrm{kg}\end{array}$ & $\begin{array}{l}\text { "Exchangeable" } \\
\mathrm{mg} / \mathrm{kg}\end{array}$ & $\begin{array}{c}\text { In ssoil } \\
\text { solution } \\
\text { mg/l }\end{array}$ \\
\hline Unlimed 0 & 207 & 55 & 54 & 0.08 \\
\hline P super & 244 & 74 & 64 & 0.10 \\
\hline $\mathbf{P}$ rock & 303 & 112 & 63 & 0.06 \\
\hline $2 \mathrm{P}$ super & 399 & 202 & 155 & 0.30 \\
\hline $2 \mathrm{P}$ rock & 320 & 113 & 74 & 0.23 \\
\hline Limed 0 & 237 & 107 & 56 & 0.08 \\
\hline 2P super & 344 & 130 & 89 & 0.14 \\
\hline 2P rock & 293 & 127 & 63 & 0.21 \\
\hline L.S.D. $5 \%$ & 65 & 62 & 38 & 0.15 \\
\hline
\end{tabular}

this is the part of soil phosphorus on which, under acid conditions, the phosphorus concentration of soil solution mostly depends. The figure in the last column is calculated on the basis of Freundlich's adsorption equation to correspond to the phosphorus concentration of solution in equilibrium with the nexchangeable" phosphorus found. Also these characteristics mostly reflect the various rate of phosphate application, although, owing to the large variation, the differences are not always significant.

Also in regard to these data the disturbing effect of the nonuniform distribution of the clay may be one explanation for the large variation and for some of the unlikely figures. Also the possibilities exist that the experimental area is not homogeneous, and the fertilizers have not always been carefully spread. Yet, most attention must probably be paid to the fact that the fertilizers have been for eleven years applied as surface dressing. When the samples were collected from the ploughing layer the often very dense mat of green plants were cut away and with it the part of fertilizers which was accumulated quite on the surface. Thus the average phosphorus content of the sample that represents the ploughing layer, or the layer from the surface down to the depth of $20 \mathrm{~cm}$, could be markedly decreased. It is alluring to apply this explanation particularly to some of the low analytical data obtained for the treatment with ground rock phosphate.

A picture of the vertical distribution of phosphorus in the variously treated plots is presented by the figures in Table 3 . Since samples from only one replication were available the results have to be considered with certain reserve. Yet, it is quite evident that the largest part of the fertilizer-phosphorus has been accumulated in the top two inches. This is not only true with the samples from the plots treated with rock phosphate but also with those from the superphosphate treatments. It seems that the lower application of these fertilizers have only slightly enhanced the phosphorus values, whereas the effect of the higher application is generally quite distinct.

According to the data reported in Tables 2 and 3 there seems to be no consistent evidence of a difference between the effect of these two fertilizers on the phosphorus 
Table 3. Phosphorus in soil at various depths

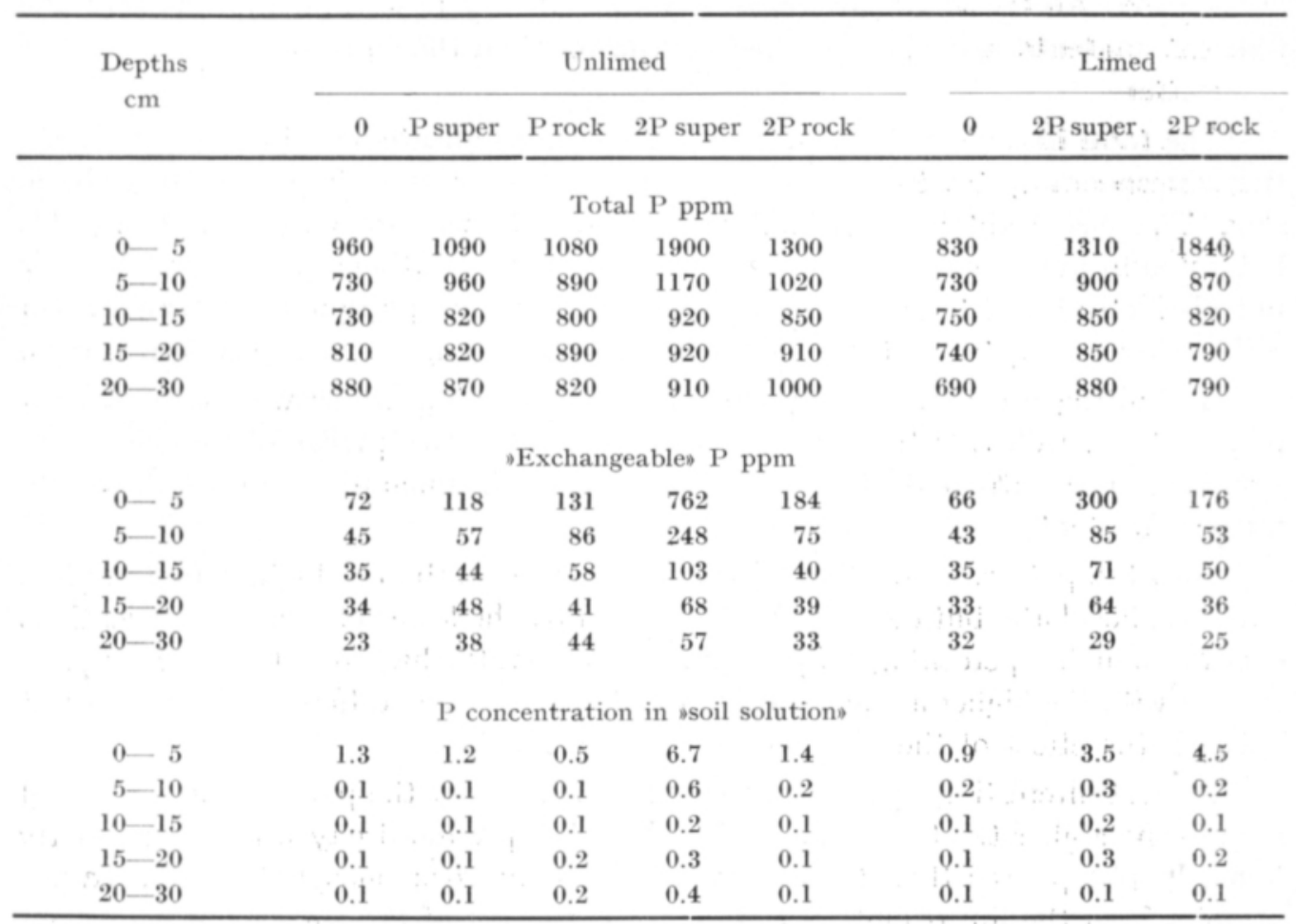

conditions of the experimental plots. However, the facts must be taken into account that probably the samples were not particularly representative, and that the variation within the replicate samples was fairly large. Therefore, it is likely that the uptake of nutrients by the crop gives a more reliable picture of the effect of the various treatments on the nutrient conditions of this peat soil.

Owing to the courtesy of the staff of Leteensuo Experiment Station the weights of the hay harvested in 1957 from the various plots were available. They are reported

Table 4. Nitrogen, potassium and phosphorus in the hay yield in 1957.

\begin{tabular}{|c|c|c|c|c|c|c|c|}
\hline \multirow{2}{*}{ Treatment } & \multirow{2}{*}{$\begin{array}{l}\text { Yield } \\
\text { kg/ha }\end{array}$} & \multicolumn{2}{|c|}{$\mathrm{N}$ in yield } & \multicolumn{2}{|c|}{$\mathbf{K}$ in yield } & \multicolumn{2}{|c|}{$\mathbf{P}$ in yield } \\
\hline & & $\%$ & $\mathrm{~kg} / \mathrm{ha}$ & $\%$ & $\mathrm{~kg} / \mathrm{ha}$ & $\%$ & $\mathrm{~kg} / \mathrm{ha}$ \\
\hline Unlimed 0 & 390 & 2.26 & 9 & 1.99 & 8 & 1.06 & 0.4 \\
\hline P super & 5450 & 1.39 & 76 & 1.78 & 97 & 1.15 & 6.3 \\
\hline $\mathrm{P}$ rock & 5240 & 1.43 & 75 & 1.81 & 95 & 1.06 & 5.6 \\
\hline $2 \mathrm{P}$ super & 7200 & 1.50 & 107 & 1.40 & 101 & 1.76 & 12.6 \\
\hline $2 \mathrm{P}$ rock & 7130 & 1.49 & 106 & 1.32 & 94 & 1.25 & 8.9 \\
\hline Limed $\quad 0$ & 330 & 2.18 & 7 & 1.84 & 4 & 1.06 & 0.4 \\
\hline $2 \mathrm{P}$ super & 7420 & 1.59 & 117 & 1.57 & 117 & 1.94 & 14.3 \\
\hline $2 \mathrm{P}$ rock & 7210 & 1.39 & 100 & 1.59 & 114 & 1.26 & 9.1 \\
\hline L.S.D. $5 \%$ & 650 & 0.28 & 16 & 0.34 & 23 & 0.24 & 1.4 \\
\hline
\end{tabular}


in Table 4 which also contains the data for total nitrogen, potassium and phosphorus in the yield. All the values are reported on the air-dry basis which means that the nutrient contents are about 15 per cent lower than the corresponding figures for dry matter.

The total hay yields harvested in 1957 do not indicate any difference between the corresponding treatments with superphosphate and rock phosphate or basic slag. The yields obtained without phosphate fertilizers are very low. The yields harvested from the plots with the lower phosphate application are fairly satisfactory but distinctly lower than those produced by the higher phosphate treatment. No difference exists between the yields of the corresponding limed and unlimed plots.

The nitrogen content of hay is equal in all the plots which were treated with phosphate regardless of the level of the application or the quality of the phosphate fertilizer. The untreated plots have produced small amounts of hay with a high nitrogen content.

Also the potassium content of the hay appears to be the highest in the plots without phosphate, but even the hay produced by the lower phosphate applications contains a higher percentage of potassium than does the hay from the unlimed plots treated with the higher amounts of phosphate. There is no difference in this respect between the effect of the phosphorus fertilizers.

A most interesting result is revealed by the data for the phosphorus content of hay: in the higher treatments superphosphate has produced hay which is distinctly richer in phosphorus than that harvested from the rock phosphate plots. In the samples from the limed plots the phosphorus content of the "superphosphate hay" is $1.94 \%$ whereas that of the wrock phosphate hay" is only $1.26 \%$. The corresponding data for the unlimed plots are $1.76 \%$ and $1.25 \%$, respectively. These differences. are highly significant. The difference between phosphorus content of the hay samples from the plots treated with the lower amounts of phosphate is statistically nonsignificant, although even in this case a tendency to the superiority of the "superphosphate hay" may be detected: the figures are $1.15 \%$ and $1.06 \%$, respectively.

Since the yields produced by the corresponding phosphate treatments were equal, the amounts of phosphorus taken up by the crop in the superphosphate plots are higher than those harvested from the rock phosphate plots. For the 2P-treatments the former were 12.6 and $14.3 \mathrm{~kg} / \mathrm{ha}$ whereas the latter were 8.9 and $9.1 \mathrm{~kg} / \mathrm{ha}$ in the unlimed and limed plots, respectively. The phosphorus yield of the lower superphosphate treatment, $6.3 \mathrm{~kg} / \mathrm{ha}$, is not significantly higher than the corresponding phosphorus yield from the rock phosphate plots, $5.6 \mathrm{~kg} / \mathrm{ha}$.

In order to find out to what kind of compounds the difference in the phosphorus content between the "superphosphate hay" and the "rock phosphate hay" is attributed, a simple fractionation of phosphorus in the hay samples from the 0 -treatments and 2P-treatments was performed. Phosphorus in ethanol extract, in $0.5 \mathrm{~N} \mathrm{HCl}$ extract, and in the residue was determined. The ethanol soluble phosphorus and residue phosphorus were supposed to represent organic compounds, although this assumption is not quite justified (cf. 8). Total phosphorus and inorganic phosphorus were determined in the acid extract. Since there were no distinct differences in the 
amounts of the various forms of organic phosphorus between the hay samples only the total inorganic and organic phosphorus contents are reported:

$\begin{array}{ccc} & \text { Inorganic } \mathrm{Pg} / \mathrm{kg} & \text { Organic } \mathrm{P} \mathrm{g} / \mathrm{kg} \\ \text { Unlimed } 0 & 0.42 & 0.65 \\ \text { 2P super } & 1.09 & 0.73 \\ \text { 2P rock } & 0.65 & 0.65 \\ \text { Limed } 0 & 0.41 & 0.69 \\ \text { 2P super } & 1.21 & 0.72 \\ \text { 2P rock } & 0.63 & 0.73 \\ \text { L.S.D. 5\% } & 0.20 & 0.10\end{array}$

These figures indicate an equal content of organic phosphorus in all the hay samples, including those from the untreated plots. Thus, the differences in the total phosphorus content are proved to be due to the inorganic fraction.

Since it is known that magnesium and probably also calcium play a role in the phosphorus metabolism of plants, also the calcium and magnesium content of the hay samples was determined. The following data expressed on the basis of air-dry matter were obtained:

$\begin{array}{ccc} & \mathrm{Ca} \% & \mathrm{Mg} \% \\ \text { Unlimed } 0 & 0.51 & 0.17 \\ \text { 2P super } & 0.37 & 0.11 \\ \text { 2P rock } & 0.39 & 0.12 \\ \text { Limed } 0 & 0.50 & 0.14 \\ \text { 2P super } & 0.42 & 0.14 \\ \text { 2P rock } & 0.38 & 0.12 \\ \text { L.s.S. 5 \% } & 0.10 & 0.05\end{array}$

These data do not indicate any significant difference in the calcium or magnesium content of the hay produced by superphosphate or rock phosphate.

\section{Discussion}

It is not always easy to choose the basis for comparison when the effect of two fertilizers containing the nutrient in differently available form is examined. In the present field trial the rates of superphosphate and basic slag were chosen so that equal amounts of ammonium citrate soluble phosphorus in the former fertilizer and citric acid soluble phosphorus in the latter one were applied. No informations are available of the basis on which the amounts of rock phosphate were calculated. The total phosphorus content of this finely ground North-African raw phosphate varies from $25 \%$ to $34 \%\left(\mathrm{P}_{2} \mathrm{O}_{5}\right)$. Finnish superphosphate contains water soluble $\mathrm{P}_{2} \mathrm{O}_{5}$ about $17-20 \%$. Thus the amount of total phosphorus which was annually applied in rock phosphate is, on the average, twice as high as the amount of water soluble phosphorus in the corresponding superphosphate treatment.

According to the results of the field trial in 1957 equal hay yields were produced by $100 \mathrm{~kg}$ of superphosphate and $130 \mathrm{~kg}$ of rock phosphate. The same holds true also 
with the treatments with $200 \mathrm{~kg}$ of superphosphate and $260 \mathrm{~kg}$ of rock phosphate both on the limed and unlimed plots. But if the phosphorus yields are compared it is found that relatively more rock phosphate is needed. It may be estimated on the basis of the phosphorus yield curves that in this particular soil the following amounts of superphosphate and ground rock phosphate correspond to each other:

$\begin{array}{ccc}\text { superphosphate } & \text { rock phosphate } & \text { ratio rock/super } \\ 85 \mathrm{~kg} / \mathrm{ha} & 130 \mathrm{~kg} / \mathrm{ha} & 1.5 \\ 100 & 170 & 1.7 \\ 140 & 260 & 1.9\end{array}$

The amount of phosphorus harvested in the hay from the plots treated with $200 \mathrm{~kg} / \mathrm{ha}$ of superphosphate was exactly twice as high as that from the plots treated with 100 $\mathrm{kg} / \mathrm{ha}$ of superphosphate. The uptake of rock phosphate phosphorus was relatively lower from the higher applications.

It has been emphasized that the present trial is no model experiment for the comparison of superphosphate and rock phosphate. It is difficult to estimate whether the residual effect of basic slag last applied ten years ago would differ from the corresponding effect of rock phosphate. In grassland trials of long standing LASKE (5) found that in acid mineral soils the soft rock phosphates were equal to basic slag in their effects on hay yields, phosphorus uptake and residual soil phosphorus.. We can only hope that the same holds true also in regard to the present trial.

The most interesting result in this study is the low phosphorus content of hay in the rock phosphate plots. It is usually considered important that hay contains at least about $0.22 \%$ phosphorus (5). According to the present data only hay from the plots treated with $200 \mathrm{~kg} / \mathrm{ha}$ of superphosphate barely meets this requirement. In this peat soil rock phosphate has, under the conditions of the year 1957, been able to produce hay containing only $0.14-0.15 \%$ phosphorus of dry matter. It cannot be estimated on the basis of the available data how high applications of rock phosphate would be needed to reach the phosphorus level of hay of a good quality.

It could be expected that one reason for the different phosphorus content of the hay produced by superphosphate and rock phosphate, respectively, may be found in the botanical composition of the hay. This was studied but no distinct divergence in this respect could be detected. The timothy content varied in all the phosphate treatments within the same limits and the rest contained Poa, Festuca, Agrostis, and Deschampsia species.

Marked differences in the ability of plants to feed on rock phosphate are known to exist. About 40 years ago TrUOG (7) connected it with the calcium uptake by plant, and nowadays it is more exactly attributed to the root cation exchange capacity (1). Monocotyledoneus plants are usually considered to be low in calcium uptake and therefore also poor feeders on rock phosphate.

This may, at least partly, explain the differences in the phosphorus uptake by the graminaceous crop from superphosphate and rock phosphate. Since the corresponding hay yields were equal it is obvious that these plants manage to produce organic matter in spite of the fairly low phosphorus content of the plant cells. The 
organic phosphorus content of all the hay samples was of the same magnitude which probably represents at least the minimum content absolutely necessary for the life of the cells. But it seems that the inorganic phosphorus content of the cells may vary quite markedly without any effect on the amount of organic matter synthesized.

The effect of rock phosphate has been studied in a lot of field trials in Finland. As far as the author knows, no particular attention has been paid to the phosphorus content of the crops. The result reported in the present paper may only be an exceptional case, particularly attributed to the fact that rock phosphate was applied as surface dressing and accumulated in the top layer. If, however, ground rock phosphate generally produces crops low in phosphorus the problem is more important. In every case, it needs further study.

\section{$S u m m$ ary}

Results are reported from a field trial on acid fen peat soil in which the effects of superphosphate and ground soft rock phosphate were compared as annual surface dressing on an old timothy ley. Until 1948 basic slag was used instead of rock phosphate; since that rock phosphate had been applied for ten years.

Owing to the large variation in the results from the replicate plots the differences in the phosphorus conditions between the various treatments were less distinct than could have been expected. The accumulation of phosphorus quite in the surface layer was demonstrated.

The hay yield produced by the annual dressing with $100 \mathrm{~kg} / \mathrm{ha}$ of superphosphate in 1957 was equal to that produced by $130 \mathrm{~kg} / \mathrm{ha}$ of rock phosphate. Also the yields from the treatments with $200 \mathrm{~kg} / \mathrm{ha}$ of superphosphate or $260 \mathrm{~kg} / \mathrm{ha}$ of rock phosphate were equal in size, but a significant difference was found in the phosphorus content of hay. In the superphosphate plots the P-content was about $0.21-0.23$ per cent of dry matter, whereas in the rock phosphate plots only $0.14-0.15$ per cent $\mathrm{P}$ in the dry matter was found.

\section{REFERENCES}

(1) Drake, M. \& Stechel, J. E. 1955. Solubilization of soil and rock phosphate as related to root cation exchange capacity. Soil Sci. Soc. Amer. Proc. 19:449-450.

(2) Karla, A. 1952. Observations on the effect of nitrogen and phosphorus upon the humification of straw. Acta Agr. Fennica 78,2.

(3) $\rightarrow$ \& KiveкÄs, J. 1956. Distribution of extractable calcium, magnesium, potassium, and sodium in various depths of some virgin peat soils. J. Sci. Agr. Soc. Finland 28: 237-247.

(4) $\rightarrow$ \& VIRTANEN, O. 1955. Determination of organic phosphorus in samples of peat soils. Ibid. 27: $104-115$.

(5) LASKE, P. 1956. Langjährige Wiesendüngungsversuche mit weicherdigen nordafrikanischen Rohphosphaten auf sauren Mineralböden. Landw. Forsch. 9: 19-24.

(6) TERÄsvuORI, A. 1954. Uber die Anwendung saurer Extraktionslösungen zur Bestimmung des Phosphordüngerbedarfes des Bodens, nebst theoretischen Erörterungen über den Phosphorzustand des Bodens. Publ. Staatl. Landw. Versuchsw. Finnland Nr 141. Helsinki. 
(7) TRUOG, E. 1916. The utilization of phosphates by agricultural crops, including a new theory regarding the feeding power of plants. Wis. Agr. Exp. Sta. Res. Bul. 41.

(8) Wenzel, W. 1956. Entwicklung einer Methode zur Bestimmung von Phosphatid-Phosphorsäure in Pflanzensubstanz. Z. f. Pflanzenern,. Düng. u. Bodenk. 75: 143-161.

S E L OS T U S :

FOSFORILANNOITTEIDEN VAIKUTUKSESTA TURVEMAALLA

\author{
Armi KaILA
}

Yliopiston maanviljelyskemian laitos, Helsinki

Tutkimuksessa on vertailtu Leteensuon koeasemalta saatujen maa- ja heinănäytteiden perusteella vuotuisen superfosfaatti- ja hienofosfaattilannoituksen vaikutusta mutasuolla. Koe oli aloitettu vuonna 1930 ja siinä oli vuoteen 1948 käytetty hienofosfaatin asemesta tomasfosfaattia. Viimeisten kymmenen vuoden aikana superfosfaatti ja hienofosfaatti oli annettu pintalannoituksena timoteinurmelle, josta vuonna 1957 korjattiin kahdestoista heinä.

Koealueen epätasaisuuden takia vaihtelut kerrannaisruuduilta otettujen maanäytteiden analyysitulosten välillä olivat suuret eikä selvää eroa eri lannoitteiden vaikutuksessa maan fosforitilanteeseen voitu todeta.

Vuotuinen $100 \mathrm{~kg} / \mathrm{ha}$ superfosfaattia tai $130 \mathrm{~kg} / \mathrm{ha}$ hienofosfaattia antoi yhtä suuret heinäsadot vuonna 1957, samoin $200 \mathrm{~kg} / \mathrm{ha}$ superfosfaattia ja $260 \mathrm{~kg} / \mathrm{ha}$ hienofosfaattia. Mutta heinän fosforin pitoisuus oli hienofosfaattia saaneissa koejäsenissä paljon matalampi kuin vastaavilla superfosfaattiruuduilla: edellisissä noin $0.14-0.15 \% \mathrm{P}$ ja jälkimmäisissä noin $0.21-0.23 \% \mathrm{P}$. Mikäli tapaus ei ole yksinäinen poikkeus, on syytä kiinnittää huomiota siihen, että hienofosfaatilla lannoitettu apilaton nurmi voi tuottaa fosforin pitoisuudeltaan eläinten rehuksi ala-arvoista heinäă. 